\title{
The Impact of Human Resource Information System (HRIS) Applications on Organizational Performance (Efficiency and Effectiveness) in Jordanian Private Hospitals
}

\author{
Iyad Mohammad Ali Khashman \\ Jazan College of Technology, Saudi Arabia, Jazan \\ E-mail: i.khashman@hotmail.com
}

Aysar Mohammad Khashman (Corresponding author)

World Islamic Sciences and Education University (W.I.S.E), Amman, Jordan

E-mail: Aysarmak@yahoo.com

$\begin{array}{lrr}\text { Received: May 4, } 2016 & \text { Accepted: June 8, } 2016 & \text { Published: July 1, } 2016 \\ \text { doi:10.5296/jmr.v8i3.9419 } & \text { URL: http://dx.doi.org/10.5296/jmr.v8i3.9419 }\end{array}$

\begin{abstract}
This study aimed to investigate the impact of human resource information system (HRIS) on organizational performance in Jordanian private hospitals, through examining if the (HRIS) components (job analysis, recruitment, selection, performance appraisal applications, and communications) have a significant impact on organizational performance (efficiency, effectiveness). The data was collected using a questionnaire instrument. The population of the research included all private hospitals located in Amman city, the number of private hospitals located in Amman were 39 hospitals whereas the sample of the research included (170) employees working in HR departments from the private hospitals. The result of this study showed that there are a positive impact of the HRMS applications on organizational performance, More specifically, it was found that and a positive attitudes from employees working in Human resources sections in private hospitals towards all human resource information system applications. The result of the study also indicated that employees working in human resources' sections in private hospitals have positive attitudes towards organizational performance which includes efficiency and effectiveness. The research recommended that
\end{abstract}




\section{Macrothink

hospitals should focus on human resource information system applications in the work environment to achieve positive outcome and maximize organizational performance at all level.

Keywords: human resource information system (HRIS), Business performance. 
In today's knowledge-based economy, Technology is playing a key role in shaping every area of our life. The Advances in technology brings innovative techniques and methods of doing business in the world of competitive corporates. Technological innovation in every business function has significant impact on performance of organizations and it helps to improve the competitiveness of the firms and thus increasing the company's value (Nohria and Gulati, 1996). The success of organizations depends largely on the performance of human resource management (Lippert and Swiercz, 2005; Troshani et al., 2011). in addition, (HRM) recently turned its concentricity on sharing of knowledge and strategic analysis of the workforce and has been increasingly evolving into a considerable contributor on the organizational strategic management (Rodriguez and Ventura, 2003; Troshani et al., 2011).

Over the past few decades, organizations have been using HRIS more to manage their human talented (Ngai \& Wat, 2006). Organizations began to electronically automate many of processes by introducing specialized HRIS to reduce the routine transaction and traditional HR activities and to deal with the complex transformational ones. HRIS refers to the systems and processes at the intersection between human resource management and information technology, it's an integrated database shared by HR functions that provides a common language and the integration of HR services. Therefore; in order to increase the effectiveness of HRM. Organizations are becoming more dependent on HRIS (Ball, 2001; Lippert \& Swiercz, 2005). At the functional level, HRIS can keep track of employees', applicants', and contingent workers' conditions, demographics, performance appraisal, professional development, payroll, recruitment, and retention (Troshani, et al., 2011). One of the basic changes has been the modern use of Information System in support of HR process (Hagood \& FriedmaHn, 2002). Thus, organizations today's are becoming heavily dependent on HRIS to raise the effectiveness of human resource management (Lippert\& Michael Swiercz, 2005; Obeidat, 2012). Every organization nowadays considered HRIS as an integral part of any organization functions. It's noted that more and more organizations are developing information technology which can help the organization to achieve the goals in a timely manner, which can help organizations make more strategic decisions by benefiting from information system (Sadiq et al, 2012). Based on a review of previous literature, this study came to identify the key applications for human resources information system and its impact on organizational performance in the Jordanian Private Hospitals. Therefore, The main goal of this study is to propose a model that describes the impact of the human resources information system applications and their impact on organizational performance in the Jordanian Private Hospitals.

This paper was organized as follows: within the next section, we review relevant literature. Section three proposes the research model and hypotheses, while section four is about the research methodology in which we discuss the design of the questionnaire, sample, and data collection, hypotheses analysis and results. The last part of this paper would be our conclusion.

\section{Literature Review}

\subsection{Human resources information system (HRIS)}

HRIS has been addressed as a tool that organizations use to solve and manage a variety of issues and processes connected to managing people. On one hand, technology may be used for 
different purposes within particular HR functions for recruitment and selection, performance evaluation, compensation and benefits, training and development, health and safety, employee relations and legal issues, retention and work-life balance (Tesi, 2010). On the other hand, HRIS is an effective tool that can be used for streamlining the administrative functions of the HR department this can be achieved by creating an elaborative and relevant database. The data of an effective HRIS would have impact on many individual tasks of HR department which can include completion of training, awards received, level of education attained, number of years of service, skills, competencies, etc... It's expected that by using this data the HR department can make a contribution towards strategy formation within an organization (Sadiq et al, 2012). Human resource information system is defined by Noe and Gerhard (2007), as a computer system used to acquire, storage, manipulate, analyze, retrieve, and distribution of information related to human resources. DeSanctis (1986) explain that human resource information system is designed to support the planning, administration, decision making, and control activities of human resources management. The human resources information system is one of the sub-systems within the framework of information systems that concerns of providing all the historical, present and future information related to human resources, presenting them to the parties interested in these resources whether they are internal or external ones, to determine the value of human resources which are considered the sources that have the highest value in the economic units especially in the service and industrial projects"(Al-Tarawneh \& Tarawneh, 2012).

Hendrickson defined HRIS as "a socio-technical (integrated) system who proposes it as gather, store, and analyze information regarding an organization's human resources department comprising of computer hardware and applications as well as the people, policies, procedures and data required to manage the human resources functions" (Tesi, 2010).

\subsection{Human Resource Information System Applications}

For the purposes of this paper, we will be taking Human Resource Information System applications as follows:

\subsubsection{Job Analysis Application}

Web-based job analysis application is the software that helps HR departments to establish job analysis, which is usually performed using an online questionnaire to collect information directly from employees, supervisors, and outside subject matter experts. The software analyzes generates a job description per job surveyed. Such job descriptionis used as bases for a job evaluation (Tesi, 2010).

\subsubsection{Recruitment Application}

Recruitment involves getting the best applicant for a job, by applied procedures that provide a large pool of qualified applicants, paired with a reliable and valid selection regime. These recruitment procedures will have a substantial influence over the quality and type of skills new employees possess. Moreover; by using recommended codes of practice and to ensure justice and fair treatment for all applicants, it's expected that all jobs in the company comply with all legal requirements related to employment and equal opportunities (Mina et al, 2012). 
Recruitment system records details of recruitment and selection activities, like; cost and method of recruitment and selection and time to fill the position, and provide necessary information timely to the users.

\subsubsection{Selection Application}

Mathis and Jackson (2010) commented that the selection process is concerned with choosing qualified individuals to fill those jobs. Gatewood \& Field (2008) defined HR selection as "the process of collecting and evaluating information about an individual in order to expand an offer of employment".

The selection process in any company or organization will determine who is hired. the selection practices should be properly designed to identify competent candidates and accurately match them to the job. The use of the proper selection will increase the probability that the right person will be chosen to fill a slot. When the best people are selected for the job, productivity increases (Mina et al, 2012). Managers should understand the objectives, policies and practices used for selection, in order to be highly involved in the process from the very beginning, which reflect the responsibility of managers towards the selection process. This responsibility will help managers in making the right selection decisions while acquiring adequate information (Rosemond \& Ernesticia, 2011).

\subsubsection{Performance Appraisal Application}

Performance appraisal system forms are applied for assessing an individual's performance, highlight potential for future career advancement, most importantly, to improve the performance. It's a merit rating which should be beneficial to both parties (Organizations and individuals) and must be constantly reviewed to suit the requirement. Moreover; performance appraisal system concerned with benchmark is set against specific task performance, define and evaluate current performance. Therefore; it requires the input and output which includes: remuneration, pay rise, level of expectation, promotion and managerial planning (Abang et al, 2009). Rosemond \& Ernesticia (2011) reported that employees should know exactly what is expected of them, and how their performance and their results will be measured by the organization. A regular assessment of the individual's performance, highlighting potential and identifying training and development needs, will be enabled by formalized and systematic appraisal scheme. The most important part is that an effective appraisal scheme can improve the future performance of staff, therefore; the appraisal scheme can also form the basis for a review of the financial rewards and planned career progression. Performance appraisal system provides data on individual employee performance appraisal data, like; due date of appraisal, scores etc.

\subsubsection{Communication Application}

communications application supports regulatory communications Inter-organizational to coordinate all the various organizational activities as well as changes ( Casico, 2006).in this function, an appropriate HRIS involves a communication mechanism suitable for communicating, It is suitable to deliver the of necessary information to all customers inside and outside the organization (Mayfield, et al., 2003). 


\subsection{Organizational Performance}

Organization performance concept have many definitions which focus on the organization's ability to attain its goals by using resources in an efficient and effective manner (Daft, 2000), Organizational performance is generally indicated by effectiveness (which includes whether an organization can achieve its objectives), and efficiency (which includes whether an organization uses resources properly), satisfaction of employees and customers, innovation, quality of products or services, and ability to maintain a unique human pool, It is clear that achieving the organization's objectives depends on to what extent performance has reached which comes from the concept that ultimate goal of a business organization is higher regarding the financial performance or maximization of wealth for stake holders (Absar et al, 2010). Organization performance related to the degree of achievement of the tasks and mission at the organization, researchers used the term performance to explain the organizational transactional efficiency and input and output efficiency to solve problems faced by the organization, which enables the organization to accomplish its goals effectively and efficiently using resources effectively (Shahzad at el, 2012). Mitchell (2002) reported that organization performance has four areas to be measured such as: Relevance: is the degree to which the organization stakeholders think that the organization is relevant to their need. Effectiveness: is the degree to which the organization is successful in achieving its strategy, mission and vision. Efficiency: is how well the organization uses its resources (financial, human, physical, information). Financial Viability: is how viable the organization is not only in short, but also in the long term.

Organizational performance means the ability of an organization to achieve such objectives in regards with: high profit, quality product, large market share, good financial results, therefore; organizational performance is used to view how an enterprise is doing, for example in terms of level of profit, market share and product quality in relation to other enterprises in the same industry using different criteria such as productivity measured in terms of revenue, profit, growth, development and expansion of the organization (Timothy at el, 2011).

\subsection{HRIS and Organizational Performance}

An information technology application in HRM has been continuously increasing rapidly from the beginning of 1990. From that period, its use and impact on HRM has been attracting the researcher (Shrivastava \& Shaw, 2003). Developments in information technology have changed the HR functions within organizations. Now-a-days, many and several organizations have come under the services of an HRIS to support HR department in performing main HR functions, promote administrative efficiency, enhancing decision making, speeding up information sharing (Lengnick-Hall \& Moritz, 2003). While, Chugh (2014) noted that reducing workload by minimizing administrative tasks .one of the more advantages of HRIS it's used it as a tool to achieve greater administrative efficiency by adding values in the department of human resources. In extent, HRIS allows HR managers to take part in strategic decisions making by being informed with real time relevant information about company's human talented (Lengnick-Hall \& Moritz, 2003).

HRIS provides management with strategic information not only in employment and retention strategies, but also in merging HRIS data into large-scale company's strategy. The data 
collected from HRIS provides management with decision-making tool. Through proper HRM, firms are able to perform calculations that have effects on the business as a whole. Such calculations include health-care costs per employee, pay benefits as a percentage of operating expense, cost per hire, return on training, turnover rates and costs, time required to fill certain jobs, return on human capital invested, and human value added. It must be noted though, that, none of these calculations result in cost reduction in the HR function (DeSanctis, 1986).

The above-mentioned areas however, may realize a large savings using more complete and current data made available to the appropriate decision makers. As a result, HRIS are seen to facilitate the providing of quality information to management for make informed decisions. in particular, it supports the provision of executive reports and summaries for top management and is crucial for learning organizations that see their human resource as providing a major competitive advantage. HRIS is therefore a means that helps HR professionals perform their job roles more effectively (Broderick and Boudreau, 1992).

Researches revealed that human resources management functions in organizations have positive relationship with improving total output of the organization, therefore; applying human resources functions have been connected with better performance in financial and operational scopes in such organizations (Mina et al, 2012). Rosemond \& Ernesticia (2011) argue if an appropriate range of HR policies and processes are developed and implemented effectively, then HR will make a substantial impact on firm performance, also human resource management will be more effective if it fits the business strategy of the firm. Sadiq et al (2012) reported that HR professionals now have an increased capacity, not only to gather information, but also to store and retrieve it in a timely and effective manner. This has not only increased the efficiency of the organization, but also the effectiveness of management functions. Human resources information systems help to improve the performance of the human resources function by providing managers with information necessary to support resolutions on human resources management, which increase the efficiency and effectiveness of human resources to exploit most of the limited resources available for more output and adequate quality, particularly through controlling and reducing costs (Hayajneh et al, 2013).

\section{Research Model and Hypotheses}

In order to examine the impact of HRIS application on organizational performance in the Jordanian Private Hospitals, a conceptual model was built from two variables including: HRIS applications, (Job Analysis, Recruitment, Selection, and Performance Appraisal, communications) as independent variables. And organizational performance (Efficiency and Effectiveness) is a dependent variable. These variables are derived from review of academic literatures based on the theoretical background and review previous literature.

Three hypotheses address the associations between HRIS Applications and Organizational Performance. The three hypotheses which guided this line of inquiry are as follows:

H1: There is no statistical significant impact of information system applications (Job analysis application, Recruitment application, Selection application, Performance appraisal application) on organization performance at level $(\alpha \leq 0.05)$. 
H2: There is no statistical significant impact of information system applications (Job analysis application, Recruitment application, Selection application, Performance appraisal application) on efficiency at level $(\alpha \leq 0.05)$.

H3: There is no statistical significant impact of information system applications (Job analysis application, Recruitment application, Selection application, Performance appraisal application) on effectiveness at level $(\alpha \leq 0.05)$.

\section{Research Methodology}

The purpose of this study was to assess the impact of HRIS applications on organizational performance .Therefore, In order to investigate the aim of this study the results are presented and analyzed in this section. The study used a descriptive analysis to describe the characteristics of the respondents. The research hypotheses were presented and tested, and multiple regressions were used to test the hypotheses.

\subsection{Justification of Selecting the Quantitative Research}

The quantitative approach has provided a suitable research data collection strategy, allowing the collecting of large data amounts from a huge population. The construct was subjected to the scale reliability procedure of SPSS 11.0, using the Cronbach's Alpha Cronbach (1951), criterion to assess the internal consistency of the studied construct. The Cronbach' Alpha coefficient is above 0.75 . Thus, the value exceeds the accepted cut-off value of 0.70 , as suggested by (Nunnally, 1978). This indicates that each individual item is internally consistent and a highly degree of reliability.

\subsection{Justification of Selection the Questionnaire}

The questionnaire started with a brief description of the meaning of the main concepts, and it gave instructions on how to answer each section of the questionnaire. A preliminary draft was developed based on an extensive literature review. It includes many questions which are consistent with the research aims. For that reason, the research survey could be described as being comprehensive. It is divided into two parts: The first part includes personal information of the respondents such as gender, area of profession and years of experience. The second part includes questions related to variables that affect HRIS Applications on Organizational Performance.

\subsection{Sample Size}

The study population included all private hospitals located in the city of Amman holding a number of 39 hospitals. The questionnaire was distributed to 200 employeesof the human resources department staff in these hospitals. The questionnaire was sent directly by hand to the employees. (184) responses were collected whereas the accepted questionnaires for the statistical analysis were (170) questionnaire. Therefore the (170) are this study's sample.

\section{Data Analysis and Discussion}

The study used a descriptive analysis to describe the characteristics of the respondents. The research hypotheses were presented and tested, and multiple regressions were used to test the hypotheses. 


\section{Mll Macrothink}

Journal of Management Research

ISSN 1941-899X

2016, Vol. 8, No. 3

Table (1) shows the distribution of respondents according to their personal characteristics. This table shows that $68.2 \%$ of the study sample is males, and $31.8 \%$ females. According to the age categories of the respondents, $37.1 \%$ of the sample belong to the first category ( 20 -less than 25 years), and 38.8 percent belongs to the category ( 25 - less than 30 years), and $21.2 \%$ belongs to the category ( 30 - less than 35 years), while only 2.9 percent of respondents belongs to the category ( 35 - less than 40 years). By referring to the educational level, Table (1) shows that 8.8 percent of the sample belongs to the second category (Master), and $88.8 \%$ of them have bachelor degree and only $2.4 \%$ for Diploma. Also Table (1) shows that $51.8 \%$ of the sample have experience less than five years, the second category (6- less than 10 years) is represented by $35.3 \%$. The experience category also illustrates that $11.8 \%$, and $1.2 \%$ belongs to the third and the fourth category (11-less than 15 years), and (16-less than 20 years) respectively, the table shows that no one from the sample has experience 20 year and more.

Table 1. Description of the characteristics of a study sample

\begin{tabular}{|c|c|c|c|}
\hline & Categories & Frequencies & Percent $\%$ \\
\hline \multirow{3}{*}{ Gender } & Male & 116 & $68.2 \%$ \\
\hline & Female & 54 & $31.8 \%$ \\
\hline & Total & 170 & $100 \%$ \\
\hline \multirow{6}{*}{ Age } & 20 - less than 25 years & 63 & $37.1 \%$ \\
\hline & 25 - less than 30 years & 66 & $38.8 \%$ \\
\hline & 30 - less than 35 years & 36 & $21.2 \%$ \\
\hline & 35 - less than 40 years & 5 & $2.9 \%$ \\
\hline & 40 years and more & 0 & - \\
\hline & Total & 170 & $100 \%$ \\
\hline \multirow{6}{*}{$\begin{array}{c}\text { Educational } \\
\text { Level }\end{array}$} & Ph.D. & 0 & - \\
\hline & Master & 15 & $8.8 \%$ \\
\hline & Bachelor & 151 & $88.8 \%$ \\
\hline & Diploma & 4 & $2.4 \%$ \\
\hline & High school & 0 & - \\
\hline & Total & 170 & $100 \%$ \\
\hline \multirow{6}{*}{ Experience } & Less than 5 years & 88 & $51.8 \%$ \\
\hline & 6- less than 10 years & 60 & $35.3 \%$ \\
\hline & 11-less than 15 years & 20 & $11.8 \%$ \\
\hline & 16 - less than 20 years & 2 & $1.2 \%$ \\
\hline & 20 year and more & 0 & - \\
\hline & Total & 170 & $100 \%$ \\
\hline
\end{tabular}


Tabel 2. Arithmetic averages, standard deviation level in HRIS applications

\begin{tabular}{|c|c|c|}
\hline Statement & Mean & Standard Deviation \\
\hline Job Analysis Application & 4.294 & 0.961 \\
\hline Recruitment Application & 3.77 & 1.16 \\
\hline Selection Application & 4.47 & 0.75 \\
\hline $\begin{array}{c}\text { Performance Appraisal } \\
\text { Application }\end{array}$ & 4.08 & 0.9518 \\
\hline $\begin{array}{c}\text { Communication } \\
\text { Application }\end{array}$ & 4.78 & 0.9372 \\
\hline Total & 4.2788 & \\
\hline
\end{tabular}

Table (2) shows the statistical analyses for all respondents according to their answers on the statements related to Job analysis application. All paragraphs in table 2 got the arithmetic mean of the highest 3.77, which is greater than 3.00, and level 0.00 observation level, This table reveals that there are positive attitudes towards all of statements related to Job analysis application because their means and total mean are greater than the standard mean, the mean value of job analysis application equal (4.29). Also this table reveals that there are positive attitudes towards all of statements related to Recruitment application because their means and total mean are greater than the standard mean, the mean value of recruitment application equal (3.77). As well, this table shows that there are positive attitudes towards all of statements related to Selection application because the mean value of Selection application equal (4.47). This table also shows that there are positive attitudes towards all of statements related to Performance appraisal application because their means and total mean are greater than the standard mean, the mean value of Performance appraisal application equal (4.08). Finally, this table reveals that there are positive attitudes towards all of statements related to communication application because their means and total mean are greater than the standard mean; with mean value of Communication Application equal (4.78).

Tabel 3. Arithmetic averages, standard deviation level in organizational performance

\begin{tabular}{|c|c|c|}
\hline Statement & Mean & Standard Deviation \\
\hline Efficiency & 4.5062 & 0.57673 \\
\hline Effectiveness & 4.5264 & 0.59698 \\
\hline Total & 4.5164 & \\
\hline
\end{tabular}

Table (3) shows the result of answers on the statements related to organizational performance, All paragraphs in table 3 got the arithmetic mean of the highest 4.50 which is greater than 3.00 , and level 0.00 observation level that shows that there are positive attitudes towards all of statements related to Efficiency because their means and total mean are greater than the standard mean, the mean value of Efficiency equal (4.50). the table also show the answers on the statements related to Effectiveness, this table reveals that there are positive attitudes 
towards all of statements related to Effectiveness because their means and total mean are greater than the standard mean, the mean value of Effectiveness equal (4.52).

Based on the objectives and hypotheses of the study, the researchers applied the multiples regression Analysis. Tables 2,3and 4 represent the test of the hypotheses by using multiples regression Analysis, based on the significant level of (0.05).

Table 4. Shows the results of the multiple linear regression analysis to test the effect of HRIS on Organization Performance

\begin{tabular}{|c|c|c|c|}
\hline R Square & Adjusted R Square & F & Sig. \\
\hline 0.450 & 0.433 & 26.807 & $0.000^{\mathrm{a}}$ \\
\hline
\end{tabular}

F-test was used to test main hypotheses as shown in table (4) it was found that calculated F value equals (26.807) and the significance of " $F$ " value is (.000) which is less than $(\alpha \leq 0.05)$ comparing with tabulated $\mathrm{F}$ value which equals (2.21). This provides evidence to reject the main hypotheses that states: There is no statistical significant impact of human resource information system applications (Job analysis application, Recruitment application, Selection application, Performance appraisal application, Training application) on organizational performance. R square for the model is (0.433), which means that human resource information system applications determine or explain about 43 percent of the organizational performance for the private hospitals in Jordan.

Table 5. The results of the multiple linear regression analysis to test the effect of HRIS on efficiency

\begin{tabular}{|c|c|c|c|}
\hline R Square & Adjusted R Square & F & Sig. \\
\hline 0.436 & 0.419 & 25.395 & $0.000 \mathrm{a}$ \\
\hline
\end{tabular}

The result of F-test related to the first sub hypotheses as shown in table (5), found that calculated $\mathrm{F}$ value equals (25.395) and the significance of " $\mathrm{F}$ " value is (.000) which is less than $(\alpha \leq 0.05)$ comparing with tabulated $F$ value which equals (2.21). This provides evidence to reject sub hypotheses that states: There is no statistical significant impact of information system applications (Job analysis application, Recruitment application, Selection application, Performance appraisal application) on efficiency. R square for the model is (0.419), which means that human resource information system applications determine or explain about $41.9 \%$ of efficiency forthe private hospitals in Jordan.

Table 6. The results of the multiple linear regression analysis to test the effect of HRIS on effectiveness

\begin{tabular}{|c|c|c|c|}
\hline R Square & Adjusted R Square & F & Sig. \\
\hline 0.433 & 0.416 & 25.068 & $0.000 \mathrm{a}$ \\
\hline
\end{tabular}

The result of F-test related to the second sub hypotheses as shown in table (6) found that calculated F value equals (25.068) and the significance of " $F$ " value is (.000) which is less than 
$(\alpha \leq 0.05)$ comparing with tabulated $\mathrm{F}$ value which equals $(2.21)$. This provides evidence to reject the sub hypotheses that states: There is no statistical significant impact of information system applications (Job analysis application, Recruitment application, Selection application, Performance appraisal application, Training application) on effectiveness. R square for the model is (0.416), which means that human resource information system applications determine or explain about 41 percent of effectiveness for the private hospitals in Jordan.

The result of this study shows that human resource information system applications (Job analysis application, Recruitment application, Selection application, Performance appraisal application) have direct and a positive impact on the organizational performance. Also the result of this study indicated that employees work in human resources sections in private hospitals have a positive attitudes towards organizational performance affected by the high mean value of statements related to efficiency and effectiveness. Moreover; the positive attitudes towards efficiency and effectiveness reflected by the believes of the sample regarding the human resources applications which is responsive to multi-organizational priorities systems, and help to encourages improvement in the operations of the hospitals, because it gives clear image of hospital performance, and because it can be completed with other computerized applications to increase the performance.

\section{Conclusion}

This paper is an attempt to build a more complete framework of the factors which influence the organization performance. The paper showed the role of HRIS Applications that affected on achieving organizational performance by providing the members of the organization with real information which enable them to take correct decisions to enhance organization performance. This research contributes to the understanding of the HRIS applications and organization performance in the literature. It describes an integration of HRIS applications and organization performance. Hopefully these conclusions will shed some light for policy makers and allowing them to increase attention to the HRIS applications because of their importance in improving organization performance.

\section{References}

Abang A., May C., \& Maw K. (2009). Human resources practices and organizational performance incentives as moderator. Journal of academic research in economics, 1(2).

Absar, M., Nimalathasan, B., \& Jilani, A. (2010). Impact of HR Practices on Organizational Performance in Bangladesh. IJBIT, 3(2).

Al-Tarawneh, M., \& Tarawneh, H. (2012).The Effect of Applying Human Resources Information System in Corporate Performance in the Banking Sector in Jordanian Firms, Intelligent Information Management, 4, 32-38.

Ball, K. S. (2001). The use of human resource information systems: A survey. Personnel Review, 30(6), 667-693. http://dx.doi.org/10.1108/EUM0000000005979.

Broderick, R., Boudreau, W. (1992). Human Resource Management, Information Technology Executive, 6(2), 7- 17. 
Casico, W. F. (2006). Managing human resource: Productivity, Quality of work life, Profits (7th ed.). McGraw-Hill.

Chugh, R. (2014). Role of Human Resource Information Systems in an Educational Organization. Journal of Advanced Management Science, 2(2), 149-153.

Daft,R.L.(2000). Organization Theory and Design (7th ed.) South-Western College Publishing, Thomson earning. U.S.A.

DeSanctis, G. (1986). Human resource information systems: A current assessment, MIS Quarterly, March, 15-27.

Gatewood, R. D., Field, H. S., \& Barrick, M. (2008). Human resource selection (6th ed.). South Western: Thomson.

Hagood, W. O., \& Friedman, L. (2002). Using the balanced scorecard to measure the performance of your HR information system. Personnel Management, 31(4), 543-557.

Harris, D. M. \& Desimone, R. L. (1995). Human resource development. TX: Dryden Press,Forth Worth.

Hayajneh O., Al-Omari B., Al-Mobaideen H., \& Allahawiah, S. (2013). The Impact of human resources information systems and training needs in industrial firms: Aqaba case research, European Scientific Journal, 8(25).

Lengnick-Hall, M. L., \& Moritz, S. (2003). The Impact of e-HR on the human resource management function. Journal of Labor Research, 24(3), 365-379.

Lippers, S. K., \& Swiercz, P. M. (2005). Human resource information systems (HRIS) \& technology trust. Journal of Information Science, 31(5), 340-353. http://dx.doi.org/10.1177/0165551505055399

Mathis, R. L., \& Jackson, J. H., (2010). Human resource management. (13th ed.). South-Western College Pub.

Mayfield, M., Mayfield, J., \& Lunce, S. (2003). Human resource information systems: a review \& model development. American Society for Competitiveness, 11(1).

Mina B., Mehdi K.., \& Yaser G. (2012). Researching the impact of human resources functions on organizational performance using structural equations method (case research: Iran Behnoush Company), Interdisciplinary journal of contemporary research in business, 3(9).

Mitchell, H. (2002). Strategic worth of human resources driving organizational performance, Universalia printed.

Ngai, E.W.T., \& Wat, F. K. T. (2006). Human resource information systems: a review and empirical analysis. Personnel Review, 35(3), 297-314. http://dx.doi.org/10.1108/00483480610656702

Nohria, N., \& Gulati, R. (1996). Is slack good or bad for innovation? Academy of Management Journal, 39, $245-64$. 


\section{Macrothink}

Nunnally, J. C. (1978). Psychometric theory (2nd ed.). New York, NY: McGraw-Hill.

Obeidat, B. Y. (2012). The Relationship between Human Resource Information System (HRIS) Functions and Human Resource Management (HRM) Functionalities. Journal of Management Research, 4(4), 193. http://dx.doi.org/10.5296/jmr.v4i4.2262

Rodriguez, J. M., \& Ventura, J. (2003). Human resource management systems \& organizational performance: an analysis of the Spanish manufacturing industry. International Journal of Human Resource Management, 14(7), 1206-1226.

http://dx.doi.org/10.1080/0958519032000114273

Rosemond B., \& Ernesticia L. (2011). The Effect of Human Resource Management Practices on Corporate Performance: A Research of Graphic Communications Group Limited. International Business Research, 4(1).

Sadiq, U., Ahmad, F., Khurram I., \& Bahaudin, G. (2012). The Impact of Information Systems on the Performance of Human Resources Department. Journal of Business Studies Quarterly, 3(4), 77-91.

Shahzad, F., Luqman, R., Khan, A., \& Shabbir, L. (2012) Impact of Organizational Culture on Organizational Performance: An Overview. Interdisciplinary Journal of Contemporary Business Research, 3(9).

Shammy S. (2012). Effectiveness of Human Resource Information System on HR Functions of the Organization: A Cross Sectional Research.US-China Education Review, 9, 830-839.

Shrivastava, S., \& Shaw, J. B. (2004). Liberating HR through technology. Human Resource Management, 42, 201-222. http://dx.doi.org/10.1002/hrm.10081.

Tesi d. (2010) Human Resource Information Systems and the performance of the Human Resource Function, PhD theses, LiberaUniversity, Roma.

Timothy, C., Andy T., Victoria O., \& Idowu A. (2011). Effects of leadership style on organizational performance in small scale enterprises. Australian Journal of Business and Management Research, 1(7), 100-111.

Troshani, I., Jerram, C., \&Rao, S. (2011). Exploring the public sector adoption of HRIS. Industrial Management and Data Systems, 111(3), 470-488. http://dx.doi.org/10.1108/02635571111118314 